\title{
Inflation: The Cost-Push Myth
}

\author{
DALLAS S. BATTEN
}

NFLATION continues to be our greatest economic problem. This is not a particularly new revelation policymakers have called it "public enemy No, 1" at least four times in the past decade. What is puzzling is that inflation has persisted (and worsened) even though its reduction has been a primary goal of both Federal Reserve and administration policy for over 10 years.

The explanations for persistent inflation are many: uncontrollably rising wages; OPEC oll-price increases; droughts or poor harvests; large government budget deficits. The list of "causes" of inflation changes with the circumstances. If we were to take them seriously, we would conclude that inflation may be caused by nearly everything. None of these causes, however, can explain inflation consistently over time or across countries. ${ }^{1}$

This article analyzes a frequently given cause of inflation - cost-push - within a monetary framework. The cost-push view of inflation is based on the notion that prices are set by the costs of production and that prices rise only when costs rise, regardless of demand. Inflation, in this framework, is the result of the sellers of productive inputs (including labor) persistently and unilaterally raising their selling prices, causing producers' costs, and subsequently prices, to rise.

\section{WHAT TS TNELTION?}

Inflation is a persistent rise in the overall (or average) level of prices of all goods and services. This

1See, for example, Scott E. Hein, "Deficits and Inflation," this Review (March 1981), po. 3-10; and Michael Parkin, "Oil Push Inflation?" Banca Nazionale del Lavoro Quarterly Review (June 1980), pp. 163-86. definition must be distinguished from an increase in relative prices (e.g., a rise in the price of wheat or oil) which, as argued below, is not inflation. Some advocates of the cost-push view confuse relative price changes with changes in the overall price level. Consequently, they view the increase in a particular price as a contributor to inflation when in reality it is not." For example, in a study of CBS Evening News broadcasts, 61.5 percent of the reports that dealt with the topic of inflation either explicitly or implicitly identified the rising prices of individual goods as the cause of inflation. A typical report: "Inflation continued to steam along at a double-digit annual rate. ... The major factor in the surge continues to be food. ${ }^{3}$ In other words, food price increases cause the overall price level to rise. Changes in the prices of individual goods do not cause inflation, although they do affect its measurement. Individual price increases accompany increases in the measure of inflation, but tell us little about the cause of inflation.

There are an infinite number of individual prices consistent with any given overall price level. At any time, some prices are increasing, some are decreasing, while others remain unchanged. Inflation - a persist-

\footnotetext{
${ }^{2}$ For a more thorough discussion of this point, see Hans $H$, Helbling and James $\mathrm{E}$. Turley, "A Primer on Inflation: Its Conception, Its Costs, Its Consequences," this Retiew (January 1975$),$ pp. $2-8$

"Tom Bethell "TV, Inflation and Government Handouts," The Wall Street Joumal, July 8, 1980.

4 Since there are many prices in an economy and since these prices do not necessarily move together, some type of price index most be constructed in order to capture changes in the general level of prices (the overall price level). Two of the most popular price indices are the consumer price index and the implicit GNP deflator. For a discussion of the problems associated with measuring the overall price level, see Denis $\mathrm{S}$. Kamosky, "A Primer on the Consumer Price Index," this Reciety (July 1974), pp. 2-7.
} 
ent rise in the overall price level - can be detected only by observing changes in an aggregate measure of prices, not by changes in individual prices.

Since inflation is a continuous rise in the average price level, a one-time increase caused by some random shock (e.g., a drought or a reduction in the quantity of oil supplied by OPEC) is not considered inflation. Of course, this one-time increase will result in a higher overall price level, but the rate of increase of the overall price level (i.e., the rate of inflation) will be unaffected if the economy adjusts to this shock immediately. Consider the example in figure 1. Over time, the overall price level is rising at a rate equal to the slope of line $\mathrm{AB}$. (This rate of price increase is usually called the trend or underlying rate of inflation.) At point $t_{0}$, the trend is interrupted by the occurrence of a random shock (e.g., OPEC nations reduce their rate of supplying oil). It the economy adjusted to this shock instantaneously, the overall price level would increase (from $B$ to $C$ ), but the trend rate of inflation would be unaffected. (The slopes of $A B$ and $C E$ are identical.) However, such adjustments are not instantaneous. During the adjustment period $\left(t_{0}\right.$ to $\left.t_{1}\right)$, the overall price level will rise at a rate (the slope of $\mathrm{BD}$ ) that is greater than the trend rate, giving the appearance that the shock has actually increased the rate of inflation. This higher rate of price change during the adjustment period is not a continuing phenomenon, however, but simply a transitory deviation of the rate of inflation from its trend. Since these deviations do not persist, they are not considered inflation. ${ }^{5}$

\section{WHAT CAUSES INFLATION?}

As noted above, considerable confusion exists about the relationships among changes in individual prices, random shocks and the cause of inflation. Political leaders attempt to persuade us that inflation is caused primarily by either random shocks or greedy businesses and labor unions raising their prices and wages unilaterally. As we have seen, the random shock argument is fallacious. Placing the blame for inflation on business and labor is the central tenet of the cost-push

5Of course, these random shocks do cause the prices of some commodities and consequently the overall price level to rise. Other things equal, individuals will experience a decline in their purchasing power. However, these shocks are typically a temporary phenomenon and, by definition, uncontrollable. To place the blame for persistent price level increases (i.e., inflation) on continually occurring random shocks is, in essence, contending that inflation is uncontrollable. This is an undesirable approach, for if infation is ever to be eliminated, it must be considered a result of controllable events.

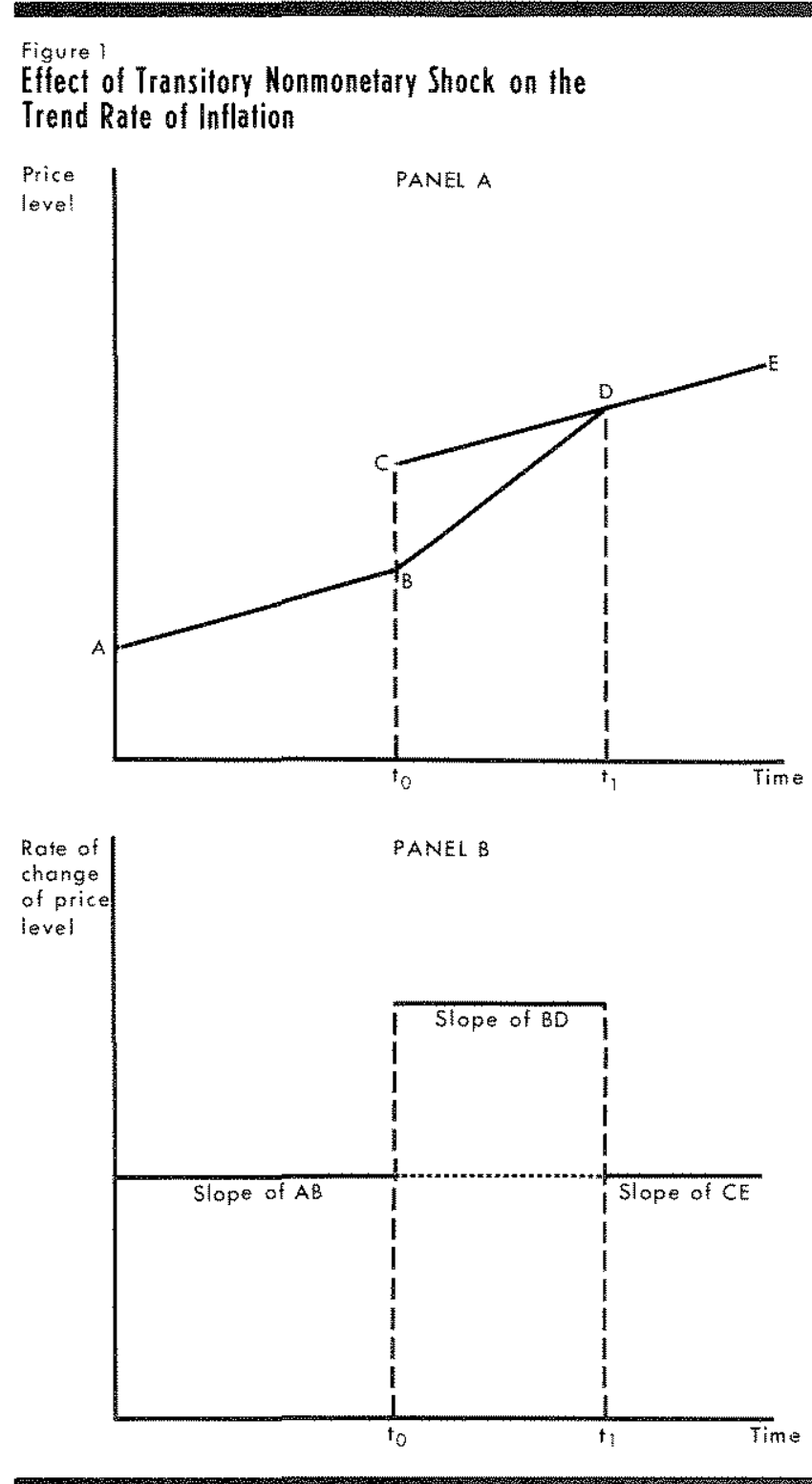

argument. This argument typically holds that businesses continually raise their prices in an effort to earn higher profits. Presumably, their ability to do this successfully stems from monopoly power.

A similar argument can be made for labor unions. Specifically, unions are alleged to exercise some monopoly power in labor markets to procure wage increases for their members greater than those dictated by market conditions. Then, the firms that employ these workers must raise their prices in order to cover these labor costs. Once this occurs, union members realize that their increased wages do not buy as many goods and services as they did before. As a result, they ask for another raise. This continuing scenario is the familiar "wage-price spiral." 
These explanations of inflation conveniently absolve government from having any role in creating inflation. The "culprits" are identified by observing which components of the overall price level rise the most at any particular time. Needless to say, the list of those contributing to inflation quickly becomes quite large: farmers (rising food prices), participants in financial markets (rising interest rates), foreigners (rising oil prices), etc. The public then believes that almost everyone is responsible for inflation, and a myriad of government agencies are formed to regulate prices in various markets, protecting some people from the presumed excesses of others. The Council on Wage and Price Stability is one such example.

\section{Money and Inflation}

To understand the fallacy of the cost-push argument, the actual cause of inflation must be identified. The ultimate source of inflation is persistent excessive growth in aggregate demand resulting from persistent excessive growth in the supply of money. This isn't a particularly novel idea - eighteenth century economists aptly described inflation as the result of "too much money chasing too few goods;" that is, the overall price level in any economy is determined by the relationship between the demand for and the supply of money. In particular, it depends on the supply of money relative to the amount that individuals desire to hold.

The quantity of money supplied is essentially a policy variable controlled by the monetary authority, the Federal Reserve System in the United States. The Fed can affect the stock of money either by changing the fraction of commercial bank and thrift institution deposits that must be held in reserve accounts with the Fed or by directly changing the level of reserves in these accounts. The Fed most frequently employs the latter method, participating in the government securities markets. Specifically, when it wants to inject reserves, it buys government securities; when it wants to drain reserves, it sells government securities.

The demand for money is the individual's desire to hold a portion of his wealth in the form of money. In the aggregate, it is determined by permanent income (the expected flow of income over one's lifetime), interest rates, prices and price expectations, An increase in permanent income motivates individuals to demand a larger stock of money. An increase in permanent income results in an increase in wealth, other things equal. Since individuals want to hold a certain percentage of their wealth in the form of money, they will add to their money balances (i.e., demand more money) as their permanent income rises in order to maintain the desired relationship between money and wealth. The interest rate is the opportunity cost of holding money, the income foregone by holding money instead of an interest-earning asset. As interest rates rise, holding money becomes relatively more costly; consequently individuals hold smaller money balances. The demand for money is positively and proportionately related to the overall price level. For example, if prices double, individuals will hold twice as much money since it will take twice as many dollars to conduct any real transaction. Finally, rising prices erode the purchasing power of the money held by individuals. If expectations of future inflation rise, individuals will attempt to hold less of their wealth in the form of money and more in some asset that will maintain its value in terms of other goods as prices rise (e.g, land or gold).

The equilibrium overall price level is the one (given the level of permanent income, interest rates and price expectations) that induces individuals to hold the exact quantity of money that the monetary authority supplies. Any other price level will motivate individuals to demand more or less money than is being supplied. If individuals are satisfied with the amount of money that they are holding, they will have no desire to increase or decrease their spending on goods and services; in other words, they are in equilibrium and the existing price level is the equilibrium one. If the money supply changes, other things equal, individuals will alter their spending in order to reach equilibrium again and, consequently, the price level will change. For example, if the amount of money supplied is greater than the amount that individuals desire to hold, an excess supply of money exists. Individuals will attempt to rid themselves of the excess money by increasing their purchases of goods and services. Thus, the existence of an excess supply of money necessarily implies a corresponding excess demand for goods and services. As individuals increase their spending, they bid up the prices of goods and services. This rise in the price level continues until individuals are motivated to hold the existing stock of money supplied by the monetary authority, that is, until equilibrium is regained. If the monetary authority continues to supply more money than is demanded, excess aggregate demand will persist and prices will continue to rise. Thus, inflation is the result of a persistent excess supply of money. 
The link between money and inflation is not confined to the United States. In fact, it is the "tie that binds" the inflationary experience of the industrialized world during the past decade. Table 1 provides a cross-country comparison of the rate of money growth and inflation over the 20-quarter period from IV/1975 to IV/1980 for the major industrial nations. ${ }^{7}$ The countries are ranked in descending order according to the rate of money growth experienced during the period. If the demand for money is relatively stable across countries, the analysis above predicts a positive relationship between money growth and inflation. This relationship can be clearly identified in the table. In particular, Italy had the highest rate of money growth and the highest rate of inflation; the United Kingdom experienced the second highest growth rates of money and prices, and so forth. ${ }^{8}$ In fact, if this comparison is continued, only West Germany violates the ordering of inflation with the rate of money growth. These results are extremely robust when one considers the heterogeneity of this group of countries.

\section{The Cost-Push Min}

Though the cost-push argument is appealing on the surface, neither economic theory nor empirical evidence indicates that businesses and labor can cause continually rising prices. All firms, regardless of the degree of competition in their industry, produce a quantity and charge a price that they expect will yield the highest profit. This price is higher in a more monopolistic market than in a more competitive one. If a firm with some monopoly power chooses to raise its price arbitrarily, the quantity that it can sell will decrease - since a monopolist faces a downward-sloping demand curve - and its profits will fall. Consequently, since profits would actually fall as prices are arbitrarily increased, a monopolist has no incentive to raise its price continually." A monopolist may charge

EFor afditional support, see "Inflation and money - the tie that binds," Citibank Monthly Economic Letter (December 1980), pp. 8-11.

The choice of a 20 -quarter period is supported by evidence presented by Denis $S$. Karnosky, "The Link Between Money and Prices - 1971-76," this Review (June I976) pp. 17-23; and Albert E. Burger, "Is Inflation All Due to Money?" this Review (Decenber 1978 ), pp. 8-12.

the Spearman rank correlation coefficient with Germany inchuded is .829 ; the calculated value when Gerriany is excluded is .997 . The critical values are .700 and .738 , respectively; that is, the hypothesis that money growth and inflation are unrelated is rejected for both cases.

In fact, one study has demonstrated that prices in highly con* centrated industries increased less rapidly during the period 1954 73 than did other prices. See Steven Lustgarten, Indus-
Table 1

\section{Money Growth and Inflation in the Major Industrial Nations (IV/1975-IV/1980)}

\begin{tabular}{|c|c|c|}
\hline Country & $\begin{array}{l}\text { Anrual rates } \\
\text { of money growt }\end{array}$ & $\begin{array}{l}\text { Annual rates } \\
\text { of lnflation }\end{array}$ \\
\hline Italy & $20.5 \%$ & $171 \%$ \\
\hline United knglom & 12,3 & 137 \\
\hline France & 100 & 107 \\
\hline West Germany & 78 & 41 \\
\hline Unted States & 75 & 9.1 \\
\hline oanada & 75 & 90 \\
\hline Japan & 72 & 6,3 \\
\hline Netherlands & 6,8 & 5.8 \\
\hline Swlzerland & 53 & 2,5 \\
\hline 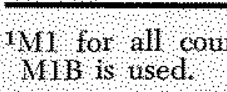 & 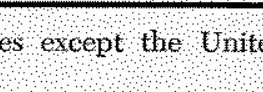 & 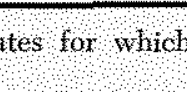 \\
\hline
\end{tabular}

higher prices than a competitive firm, but this does not imply constantly rising prices.

Unfortunately, realizing that monopolies (which wish to maximize their profits) cannot unilaterally contribute to inflation is insufficient to lay this argument to rest. A similar argument has been developed based on changes in the degree of competition within markets. Since monopolies do charge higher prices than competitive firms, prices will continue to rise if the economy becomes less and less competitive. In other words, it is often argued that inflation is the result of the acquisition of additional market power by the firms within the economy. If the economy is becoming less and less competitive, then the continually declining rate of growth of real output that results will cause prices to rise; that is, inflation caused by the acquisition of more and more monopoly power must be accompanied by less and less output being produced and sold. Chart 1 contains a comm parison of a trend rate of inflation (as measured by the consumer price index) with a trend rate of growth of real output (real gross national product). Since the trend rate of growth of real output does not show a continuously decreasing pattern, the hypothesis that increased monopolization has caused the rising inflation during the past decade can be rejected.

trial Concentration and Inflation (American Enterprise Institute for Public Policy Research, 1975), pp. 25-29. 
Chart 1

\section{Trend Rates of Inflation and Output Growth ${ }^{13}$}

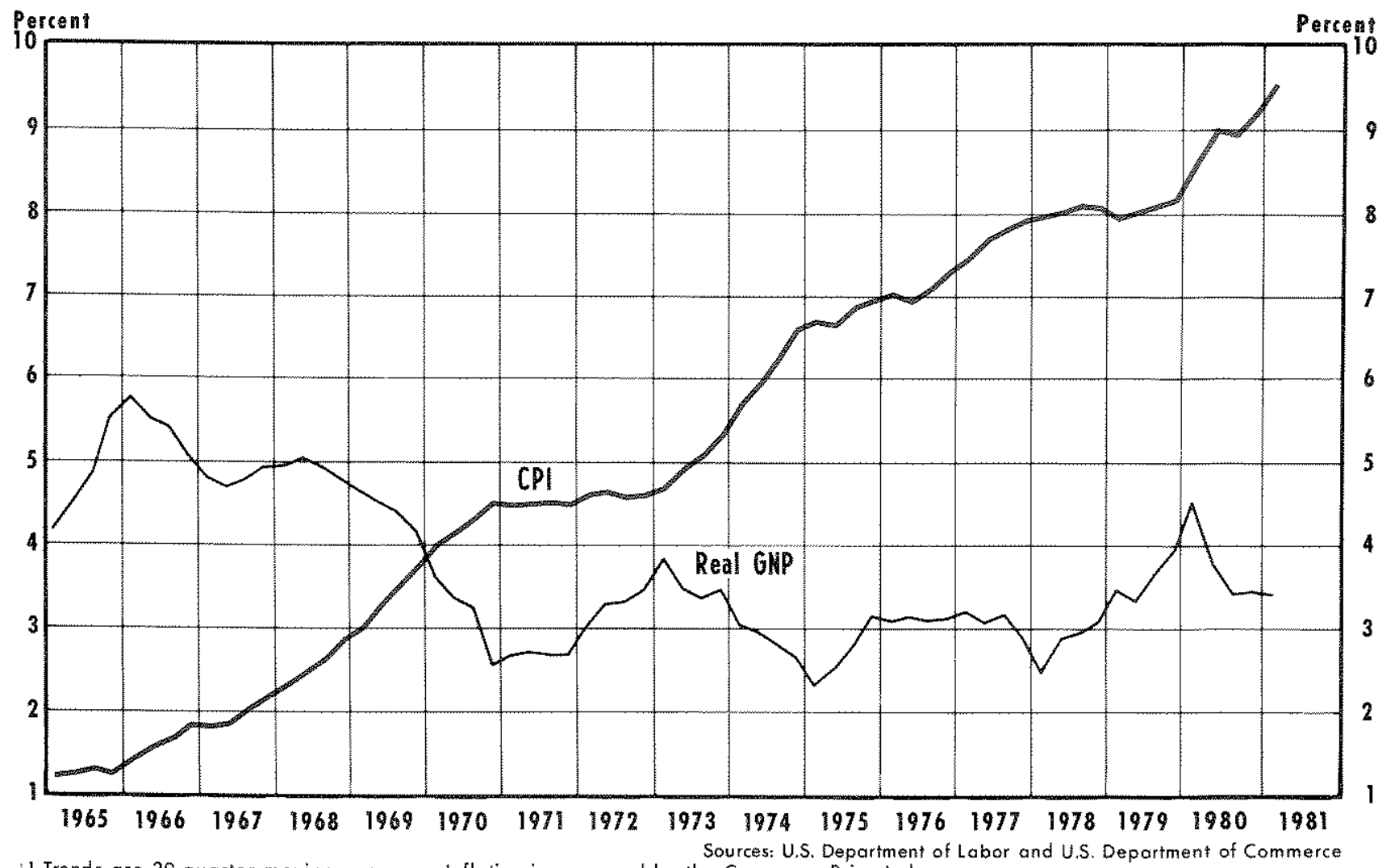

1 Trends are 20 -quarter moving averages. Inflation is measured by the Consumer Price Index.

The cost-push argument is even less credible when analyzed in a macroeconomic framework. In particular, other non-monopolized sectors of the economy adapt to the exercising of monopoly power in one sector. As a result, they tend to neutralize the monopoly's impact on the entire economy. To understand this more clearly, assume that the union in industry A succeeds in obtaining a wage increase for its members that is higher than that dictated by market conditions (i.e., the demand for A's product and the productivity of the workers in A). As a result, the firms in $A$ raise their prices in an attempt to cover the increased labor costs. ${ }^{10}$ Other things equal, these higher prices cause the overall price level to rise. Because of this price increase, individuals in the aggregate demand larger money balances. If the money supply remains unchanged, however, there is no ad-

10It should be noted that an increase in wages need not be the motivation for higher prices; higher prices could have resulted from the firms in $A$ exercising their monopoly power. The erucial point is that prices in $\AA$ have risen unilaterally, independent of market conditions. ditional money for them to hold. Consequently, in order to increase their balances to the new desired level, they must decrease their spending on goods and services.

This decreased aggregate demand will ultimately cause prices in other industries to fall until the overall price level returns to what it was prior to the wage increase. The price level must return to its original value because, other things equal (especially the money supply), it is the only price level at which the quantity of money supplied equals the quantity demanded. The wage increase in $\mathrm{A}$ has induced higher prices in A, but lower prices in other industries. The union's action has caused relative prices to change, but has not affected the overall price level. ${ }^{11}$

重The inability of a labor union (that doesn't represent the entire labor force) to affect the overall price level can be seen through the quantity equation:

$$
\mathrm{MV}=\mathrm{PQ}
$$

where $M$ is the money stock; $V$ is the velocity of money (i.e., the average number of times that the money stock 
Critics of the above scenario state that "nowadays, ... compensatory price declines tend not to occur."12 As a result, they conclude that "the rules of economics don't seem to be working any more." 13 The rules of economics, however, always work despite attempts to frustrate them. The point missed by these critics is that the monetary accommodation of a price shock prevents the occurrence of a compensatory price decrease. In the scenario above, prices in other industries fell because the money stock was held constant.

This price adjustment does not occur immediately. During the adjustment period, the cost of adjusting is reflected by reduced output. If the monetary authority confuses this loss of output (and the corresponding decline in employment) with a permanent decline in aggregate demand, he may increase the money supply. This then precludes the compensatory price declines that one expects to observe in other industries. The price level does not return to its original level and the success of the labor union in industry $\mathrm{A}$ in obtaining a higher than warranted wage increase for its members is termed a cause of infla-

circulates within the economy during a year); $\mathrm{P}$ is the overall price level; and $Q$ is real gross national product (GNP) Using the culuntity equation, the overall price level can be determined as follows:

$$
\mathrm{P}=\frac{\mathrm{MV}}{\mathrm{Q}} \text {. }
$$

Suppose that there are only two industries (A and B) in this economy. Labor in $A$ is unionized; labor in $B$ is not In this simple world, the overall price level and real GNP can be rewritten as;

$$
\begin{aligned}
& \mathrm{P}=\mathrm{w}_{\mathrm{A}} \mathrm{P}_{\Delta}+\mathrm{w}_{\mathrm{B}} \mathrm{P}_{\mathrm{B}} \\
& \mathrm{Q}=\mathrm{Q}_{A}+\mathrm{Q}_{\mathrm{B}},
\end{aligned}
$$

where $P_{A}$ and $P_{B}$ are the prices $i n$ industries $A$ and $B$, respectively; $w_{A}$ and $w_{B}$ are the pereentages of the average consumer's consumption bendle composed of $A$ 's output and $B$ 's output, respectively; and $Q_{A}$ and $O_{k}$ are the ontput of $A$ and $B$, respectively. If the action of the union in $A$ causes wages ard prices in $A$ to rise, ther the overall price level must also rise, other things equal. Since nothing has occurred that canses $M$ or $V$ to change, the new hioher $P$ is consistent with the quantity equation only if $Q$ declines. Total output (Q) must decline because $Q_{A}$ decreases as consumers react to the higher $P_{4}$ by moving up their demand curves for A. This new situation, however, cannot be one of equilibrium because there are anemployed workers that are willing to work at the current market wage. The mion's action has precluded their employment in A; conservuently, these workers must search for work in $B$. As they search for employnent in $B$, wages in $B$ decline, causing $P_{B}$ to fall and $Q_{B}$ to rise intil there are no memployed workers at the current wage Since none of these occurrences change the equitibrium num ber of employed workers (econony-wide) or the relationship between the number of workers and the quantity of ontput produced economy-wide, this equilibrating process must cortinue until $P_{B}$ has decreased (and $Q_{B}$ has increased) sufficiently for the overall price level $(P)$ and real output $(Q)$ to return to their original levels,

12"Needed: A New Perspective on Inflation," The Morgan Guaranty Survey (November 1980), p. 2.

1aIbid. tion. In fact, the actual cause of inflation has been the accommodation on the part of the monetary authority, not the monopolist, labor union, or an inherent price rigidity built into the economy.

It is difficult to support the cost-push hypothesis. Gordon, in a study of inflation in the United States, Canada, France, West Germany, Italy, Japan, Sweden and the United Kingdom for the period 1958-76, could find no support for the wage-push hypothesis: "The wage-push hypothesis appears to be alive and well as an explanation of wage rates, but not as a theory of inflation or of monetary growth." 14 In an analysis of post-World War II inflation in the United States, Barth and Bemnett concluded that "there is evidence of midirectional causality that runs from consumer prices to wages." 15 In other words, higher wages do not lead to higher prices as the cost-push hypothesis predicts; instead, higher prices lead to higher wages.

\section{The Cost-Push Illusion}

If cost-push inflation is really a myth, why do consumers hear businessmen rationalize their price increases with: "I have to raise my price because my costs have risen." Are businessmen simply trying to pass the buck? No, most businessmen (especially those operating relatively small businesses) believe that higher costs of production are the motivation for their raising prices. They seldom identify the real cause - increased aggregate demand resulting from increased money growth. The translation of increased aggregate demand into higher prices is frequently concealed in the marketplace by the existence of inventories. As a result, a "cost-push illusion" is created. ${ }^{16}$

No merchant sells his product at a constant rate; sales in some time periods are larger than normal, while sales in other time periods are smaller. In order to hedge against running out of their product during periods of larger than normal sales, merchants

1ะRobert J. Gordon, "World Inflation and Monetary Accommodation in Eight Countries," Brookings Papers on Economic Activity (2: 1977), p. 433 . Since changes in wages are the predominant calses of changes in costs of production, testing the wage push hypothesis is tantamount to testing the cost-push hypothesis.

15. Fames R. Barth and James T. Bennett, "Cost-push versus Demand pull Inflation: Some Empirical Evidence," Journal of Money, Credit and Banking (August 1975), p. 397.

16This phrase was coined by Armen A. Alchian and William R. Allen in University Economics, 3rd. ed. (Wadsworth Pablishing Company, Inc., 1972), p. 95. This discussion follows theirs. 
typically hold inventories (or buffer stocks). If aggregate demand increases, merchants cannot immediately distinguish this phenomenon from a period in which sales are temporarily above normal; that is, they do not realize inmediately that they could raise their price and still make the normal amount of sales. Consequently, they will not raise their price immediately, but instead, will draw down their inventories held for such an occasion as this. If these higher than normal sales persist, merchants will increase their purchase rate from suppliers in order to maintain their inventories at the desired level. The firms that supply these merchants thus will experience higher than normal rates of sales, and their inventories will be depleted more rapidly than desired, motivating them to increase the rates at which they purchase from their suppliers.

This process continues filtering down the network of markets until it finally reaches the market of raw materials (the primary inputs used to produce this commodity). In the raw materials markets, the amount available is insufficient to meet the increased amount demanded at the old price. ${ }^{17}$ Since aggregate demand has increased (not just the demand of one or a few manufacturers), all manufacturers want additional raw materials. As a result, all offer higher prices to suppliers until the price of raw materials is bid up enough to clear the market. Because the higher price for raw materials increases their cost of production, manufacturers will charge wholesalers a higher price for their product, citing increased raw material costs as the reason. Wholesalers will say that the increased manufacturers' price makes it necessary to charge retailers a higher price. And finally, the retailer (merchant), being completely truthful, will tell the consumer that he must charge a higher price because his costs have risen.

1TThat is, existing inventories of raw materials are insufficient to meet the increased demand.
Though it appears that increased raw material costs have caused a higher final product price, the actual cause of the higher prices at every level of the manufacturing and distribution network is the initial increase in aggregate demand for the final product. The price increase is delayed until the impact of the increased demand reaches the raw materials market by the existence of inventories at each level that are sufficient to buffer transitory, but not permanent, changes in demand at each level.

\section{SUMMART AND CONCUTSION}

The focus of this paper has been to separate the cost-push myth from the reality of inflation. The costpush argument views inflation as the result of continually rising costs of production - costs that rise unilaterally, independent of market forces. Such an hypothesis (1) confuses changes in relative prices with inflation, a continuously rising overall level of prices, and (2) neglects the role that the money supply plays in the determination of the overall price level. The idea that greedy businesses and/or labor unions can cause a continual rise in prices cannot be supported by either the conceptual development or the empirical evidence provided. Alternatively, the hypothesis that inflation is caused by excessive money growth is well supported. In the major industrial countries, those with the highest rates of inflation have the highest rates of money growth, and vice versa. Consequently, inflation cannot be eliminated by attacking those sectors of the economy that have experienced the most rapid increase in prices, by imposing wage and price controls, or even by em ploying some type of tax-based incomes policy. Inflation will be eliminated only when the long-term rate of money growth is approximately the same as the long-term rate of real output growth.

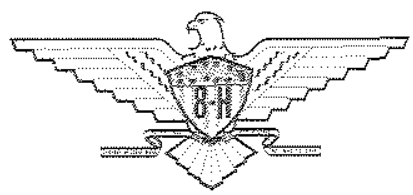

